\title{
EFFECTS OF Teucrium polium L. AND Teucrium montanum L. EXTRACTS ON MECHANISMS OF APOPTOSIS IN BREAST AND COLON CANCER CELLS
}

\author{
Danijela Nikodijević*, Milena Milutinović, Danijela Cvetković, Milan Stanković, \\ Marko N. Živanović, Snežana Marković \\ Department of Biology and Ecology, Faculty of Science, University of Kragujevac, \\ Radoja Domanovića 12, 34000 Kragujevac, Republic of Serbia \\ *Corresponding author; E-mail: dnikodijevic91@gmail.com
}

(Received April 11, 2016)

\begin{abstract}
The aim of this study was to determine the cytotoxic and proapoptotic activity of methanol extracts from Teucrium polium L. and T. montanum L. on immortalized cell lines of breast cancer (MDA-MB-231) and colorectal carcinoma (SW480). The cytotoxic activity was determined using MTT cell viability assay, where $\mathrm{IC}_{50}$ value was used as a parameter for cytotoxicity. The type of cell death was explored by fluorescence microscopy using acridine orange/ethidium bromide method. For determination apoptosis signal pathways expression of Fas receptor was monitored by immunofluorescence, while caspases 8 and 9 activity was analyzed, by colorimetric based assays. The results indicate that both plant extracts induced decrease of MDA-MB-231 and SW-480 cell viability, good cytotoxicity ( $\mathrm{IC}_{50}$ values in range of 118.26 to 429.32 $\mu \mathrm{g} / \mathrm{ml}$, depends on type of cells and extracts, as well on treatment periods) and induced apoptosis, as a dominant type of cells death (6-11\% of total cells). Investigated treatments led to increase in Fas receptor expression only in the case of T. montanum treatment on MDA-MB-231 cells. Additionaly, apoptosis was activated and realized via external pathway with the activation of internal apoptotic pathway mediated by caspases 8 i 9 in MDA-MB-231 cells while apoptosis occurred by caspase-independent pathway in SW480 cells. In conclusion, the results showed that the investigated methanol extract of Teucrium species showed good cytotoxic and proapoptotic activities, T. montanum expressed better activity, and the MDA-MB-231 cells were more sensitive to treatments.
\end{abstract}

Keywords: apoptosis, cancer, cytotoxicity, plant extracts, Teucrium polium, Teucrium montanum.

\section{INTRODUCTION}

Carcinogenesis is a complex process, where during the transformation of normal cells in tumor cells come to the accumulation of multiple genetic changes (WEINBERG, 2014). Breast cancer is the most common malignant tumor in women. Research shows that women with mutation in the BRCA1 or BRCA2 gene have $45-85 \%$ chance to be affected by tumor (ROSENBERG et al. 2016). The risk of development of this type of cancer increases with age (the largest in the period between 40 and 50 years) (BORANIĆ et al. 2006). On the other hand, 
colorectal cancer is the third most frequent in women, but it is in the first place in men (MILIĆ and DAMNJANOVIĆ, 2013).

Traditional medicine relates to the use of plants and their products for the treatment and prevention of diseases (RAVELO et al. 2004). Plants are organisms with the large quantities of bioactive compounds, and since the earliest civilizations used as prevention for many diseases, including tumors. When consider anti-tumor substances, or drugs, $60 \%$ derive from natural sources (NEWMAN et al. 2003; CRAGG and NEWMAN, 2005). Biologically active compounds present in plants are phenolic compounds, oligosaccharides, phytosterols, phytoestrogens, and polyunsaturated fatty acids (GREE et al. 2001). The most common phenols in plants are flavonoids (NIJVELDT et al. 2001). Considering that species belonging to the Teucrium genus (Lamiaceae) are very rich in phenolic compounds and have strong biological activity (HASANI-RANJBAR et al. 2010; YIN et al. 2009) the determination of antitumor effects of the plant species Teucrium polium L. and T. montanum L. in breast and colon cancer cell lines can greatly contribute to the further development of anticancer therapies. In our stady we used species $T$. polium L. and T. montanum L. selected from different localities, which greatly altered the activity of the extracts due to their different environmental conditions influencing them (STANKOVIĆ et al. 2011; STANKOVIĆ et al. 2015).

Induction of apoptosis is increasingly valued as a biologically significant anticancer mechanism and is one of the major strategies in cancer therapy (WONG, 2011). Apoptosis is a form of "active cell death" because the cells involved in this process actively, run by themselves. Therefore, apoptosis is usually called programmed cell death (ALBERTS et al. 2008; WEINBERG, 2014). As a mechanism that regulates cell number, apoptosis has an important role in the process of carcinogenesis. There are two activation pathways of apoptosis: receptor (external) and mitochondrial (internal) apoptotic pathway. The external pathway involves the binding of a ligand to receptors (this case was observed in the expression of Fas receptor), which extend from the external to the interior surface of the membrane. Parts of these receptors, which are located in the cytoplasm, are known as the death domain. Afterword they associate with receptors of signaling pathway inducing apoptosis (WONG, 2011; OUYANG et al. 2012). Key proteins involved in this process are enzymes, known as caspases. They are located in the cytoplasm as inactive proteins that are activated when it is needed. One caspase can activate other caspases thereby enhancing the stimulus for apoptosis which accelerates cell death (WEINBERG, 2014). In this case, the parameters that are monitored are associated with signal path that through the receptor leads to initiation of apoptosis and his realization.

On the basis of the literature data and actuality of antitumor therapy problem, the aim of this study was to determine the cytotoxic and proapoptotic effects of methanol extracts of plants $T$. polium L. and T. montanum L. on immortalized cell lines of breast cancer (MDAMB-231) and colorectal carcinoma (SW-480).

\section{MATERIALS AND METHODS}

\section{Chemicals}

Dulbecco's Modified Eagle Medium (DMEM) and Phosphate Buffered Saline (PBS) were obtained from GIPCO, Invitrogen, USA. Fetal Bovine Serum (FBS) and Trypsin-EDTA were from PAA (The cell culture company), Austria. Dimethyl Sulfoxide (DMSO), Ethidium bromide (EB), 3-[4,5-dimethylthiazol-2-yl]-2,5-diphenyltetrazolium bromide (MTT), Nitro Blue Tetrazolium (NBT) and Bovine Serum Albumin (BSA) were obtained from SERVA, Germany. Acridine Orange (AO) was obtained from Acros organics, New Jersey, USA. 
Polyvinyl alcohol mounting medium was obtained from Fluca Analytical, Switzerland and $p$ formaldehyde from Merck, Germany. All other solvents and chemicals were of analytical grade.

\section{Plant material}

T. polium was collected in August 2014 on Stara planina mountain in Eastern Serbia, while T. montanum was collected in July 2014 on Goč mountain in Central Serbia. The collected samples were air-dried in darkness at room temperature.

\section{Preparation of plant extracts}

Prepared plant material ( $10 \mathrm{~g})$ consisting of aerial parts of T. polium and T. montanum were transferred to dark-colored flasks. The material was separately soaked in $200 \mathrm{ml}$ of methanol and stored at room temperature. After $24 \mathrm{~h}$, the extracts were filtered through Whatman No. 1 filter paper and the residue was re-extracted with equal volume of solvents. After $48 \mathrm{~h}$, the process was repeated. Combined supernatants were evaporated to dryness under vacuum at $40{ }^{\circ} \mathrm{C}$ using Rotary evaporator. The obtained extracts were kept in sterile sample tubes and stored in a refrigerator at $4{ }^{\circ} \mathrm{C}$.

\section{Cell preparation and culturing}

Human breast cancer - MDA-MB-231 and human colon cancer - SW-480 cell lines were obtained from American Type Culture Collection. Cells were maintained in DMEM supplemented with $10 \%$ FBS, with 100 units $/ \mathrm{ml}$ penicillin and $100 \mu \mathrm{g} / \mathrm{ml}$ streptomycin. Cells were cultured in humidified atmosphere with $5 \% \mathrm{CO}_{2}$ at $37{ }^{\circ} \mathrm{C}$. Cells were grown in $75 \mathrm{~cm}^{2}$ culture bottles supplied with $15 \mathrm{ml}$ DMEM, and after a few passages, cells were seeded for different assays. All studies were done with cells at 70 to $80 \%$ confluence.

\section{Cell viability assay (MTT assay)}

The cell viability was determined by MTT assay (MOSMAN, 1983). The proliferation test is based on the color reaction of mitochondrial dehydrogenase in living cells by MTT. MDA-MB-231 and SW-480 cells were seeded in a 96-well plate $\left(10^{4}\right.$ cells per well $)$. After 24 $\mathrm{h}$ of incubation $\left(5 \% \mathrm{CO}_{2}\right.$ at $\left.37^{\circ} \mathrm{C}\right)$, the cells were treated by $100 \mu \mathrm{l}$ of methanol extracts from T. polium and T. montanum $(1,10,50,100,250$ and $500 \mu \mathrm{g} / \mathrm{ml})$. The untreated cells served as a control. The results of cell viability were determined after 24 and $72 \mathrm{~h}$ from initial treatment. At the end of the treatment period, MTT (final concentration $5 \mathrm{mg} / \mathrm{ml} \mathrm{PBS}$ ) was added to each well and incubated at $37{ }^{\circ} \mathrm{C}$ in $5 \% \mathrm{CO}_{2}$ for $2-4 \mathrm{~h}$. The colored crystals of produced formazan were dissolved in $150 \mu \mathrm{l}$ DMSO. The absorbance was measured at 570 $\mathrm{nm}$ on Microplate Reader (ELISA RT-2100C). Cell proliferation was calculated as the ratio of absorbance of treated group divided by the absorbance of control group, multiplied by 100 to give a percentage proliferation.

\section{Fluorescence microscopic analysis of cell death}

Acridine orange/ethidium bromide (AO/EB) double staining assay was used for determination of type of cell death (BASKIĆ et al., 2006). Acridine orange is taken up by both viable and nonviable cells and emits green fluorescence if interrelated into double stranded nucleic acid (DNA) or red fluorescence if bound to single stranded nucleic acid (RNA). Ethidium bromide is taken up only by nonviable cells and emits red fluorescence by intercalation into DNA. There are four types of cells according to the fluorescence emission and the morphological aspect of chromatin condensation in the stained nuclei. (1) Viable cells 
have uniform bright green nuclei with organized structure. (2) Early apoptotic cells (which still have intact membranes but have started to undergo DNA cleavage) have green nuclei, but perinuclear chromatin condensation is visible as bright green patches or fragments. (3) Late apoptotic cells have orange to red nuclei with condensed or fragmented chromatin. (4) Necrotic cells have uniformly orange to red nuclei with condensed structure. MDA-MB-231 and SW480 cells were seeded in a 96-well plate $\left(10^{4}\right.$ cells per well) and after $24 \mathrm{~h}$ treated by $100 \mu \mathrm{l}$ of methanol extracts from T. polium and T. montanum $(50 \mu \mathrm{g} / \mathrm{ml})$. The untreated cells served as a control. After 24 and $72 \mathrm{~h}$ of incubation periods, $20 \mu \mathrm{l}$ of dye mixture (10 $\mu \mathrm{l} \mathrm{AO}$ and $10 \mu \mathrm{l} \mathrm{EB}$ in distilled water) were added in all samples and immediately examined and viewed under Nikon inverted fluorescent microscope (Ti-Eclipse) at 400x magnification. A minimum of 300 cells were counted in each sample.

\section{Immunofluorescence staining for determination of Fas receptors protein expression}

Fas receptor protein expression on MDA-MB-231 and SW-480 cells was detected by immunofluorescence (Higuchi et al. 2001). Cells were cultured in 6-well plates on glass coverslips (Thermo Scientific), $7 \times 10^{4}$ cells/well. When cells were at 70 to $80 \%$ confluence, the media was aspirated and the cells were treated by $2 \mathrm{ml}$ of methanol extracts from $T$. polium and T. montanum $(50 \mu \mathrm{g} / \mathrm{ml})$. After $24 \mathrm{~h}$, the medium was aspirated and cells were washed with phosphate-buffered saline (PBS) (pH 7.2). Next, the cells were fixed with $4 \% p$ formaldehyde in PBS for $20 \mathrm{~min}$ at $37{ }^{\circ} \mathrm{C}$. After the fixation, the cells were washed three times with PBS and then permeabilized with methanol $\left(-20^{\circ} \mathrm{C}\right)$ for $2 \mathrm{~min}$, washed with PBS 3 times and non-specific binding sites were blocked using 1\% BSA for $20 \mathrm{~min}$. These fixed cells were stained with $20 \mu \mathrm{g} / \mathrm{ml}$ anti-Fas specific primary antibody (RD Systems) for $1 \mathrm{~h}$ at $37{ }^{\circ} \mathrm{C}$. Sample coverslips were then washed twice and incubated with a secondary antimouse antibody conjugated with Cy3 (Thermo Scientific) at a 1:200 dilution in PBS. DAPI was used to stain the cell nuclei (blue) at 1:1000 dilutions. Sample coverslips were then washed twice and mounted on glass slide by polyvinyl alcohol mounting medium. The cells were visualized using Nikon inverted fluorescent microscope (Ti-Eclipse) at 600x magnification. This is a visual method and the results are presented as representative pictures.

\section{Caspase 8 and 9 activities assays}

The Caspase 8 and 9 colorimetric assays (RD Systems) were performed according to the manufacturer's protocol. MDA-MB-231 and SW-480 cells were seeded in 6-well plates ( $2 \times 10^{6}$ cells per well). After $24 \mathrm{~h}$ cells were treated by $2 \mathrm{ml}$ of methanol extracts from $T$. polium and T. montanum $(50 \mu \mathrm{g} / \mathrm{ml})$. Non-treated cells served as a control. The cells were pelleted down, resuspended in $50 \mu \mathrm{l}$ of cell lysis buffer (supplied with the kit), and incubated on ice for $10 \mathrm{~min}$. After centrifuging at $10000 \mathrm{x} \mathrm{g}$ for one min, the supernatants (cytosolic extract) were transferred to fresh tubes and kept on ice. The caspase 8 and caspase 9 assays were performed according to the supplied kit protocols. $50 \mu \mathrm{l}$ of $2 \mathrm{x}$ reaction buffer (containing $10 \mathrm{mM}$ DTT) was added to each sample and $5 \mu \mathrm{l}$ of IETD-pNA substrate for caspase 8 or LEHD-pNA substrate for caspase 9 , and incubated at $37{ }^{\circ} \mathrm{C}$ for $1-2 \mathrm{~h}$. The level of caspase enzymatic activity in the cell lysate was directly proportional to the color reaction.

\section{Statistical analysis}

The data are expressed as mean \pm standard error (SE). Biological activity was examined in three individual experiments, performed in triplicate for each dose. Statistical significance was determined using the Student's $t$-test or the one-way ANOVA test for multiple comparisons. A p value $<0.05$ was considered significant. The magnitude of correlation between variables was done using a SPSS (Chicago, IL) statistical software 
package (SPSS for Windows, ver. 17, 2008). The $\mathrm{IC}_{50}$ values were calculated from the dose curves by a computer program (CalcuSyn).

\section{RESULTS}

\section{Cytotoxic effects}

Results presented in Figures 1 and 2 showed in vitro effects of the investigated plants methanol extracts on MDA-MB-231 and SW-480 cells viabilities, determined by MTT assay. T. polium and T. montanum significantly decreased MDA-MB-231 cell viability on the doseand time-dependent way (Figure 1). On the other hand, we showed that methanol extracts on SW-480 cells viabilities had stronger effects after 24 hours (Figure 2). According to the given data, the cytotoxic effects are calculated and expressed by $\mathrm{IC}_{50}$ values, concentration which inhibits $50 \%$ of cell growth (Table 1). Criteria for significant cytotoxic activity of plant extract, according American National Cancer Institute, is $\mathrm{IC}_{50}$ values lower than $30 \mu \mathrm{g} / \mathrm{ml}$ (SuFFINESS and PEZZUTO, 1990). According to this criteria, investigated plants extracts showed good, but no significant cytotoxic activity. However, from aspect of the use of plants as a supplement in antitumor therapy, these $\mathrm{IC}_{50}$ values present a significant result. Altogether these results indicate more potent cytotoxic effects of T. montanum, and more sensitive MDAMB-231 cells to treatments.

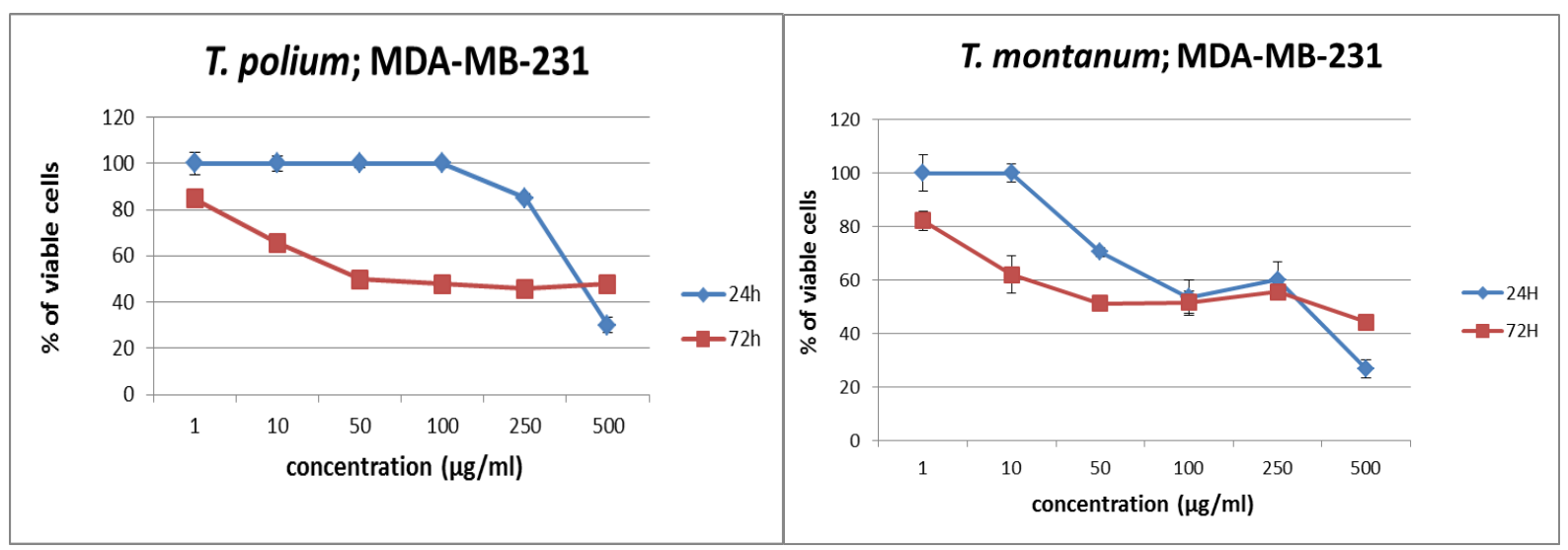

Figure 1. Cytotoxic activity of the methanol extracts from T. polium and T. montanum on MDA-MB-231 cell lines.

Results are expressed as means \pm SE for three independent determinations.

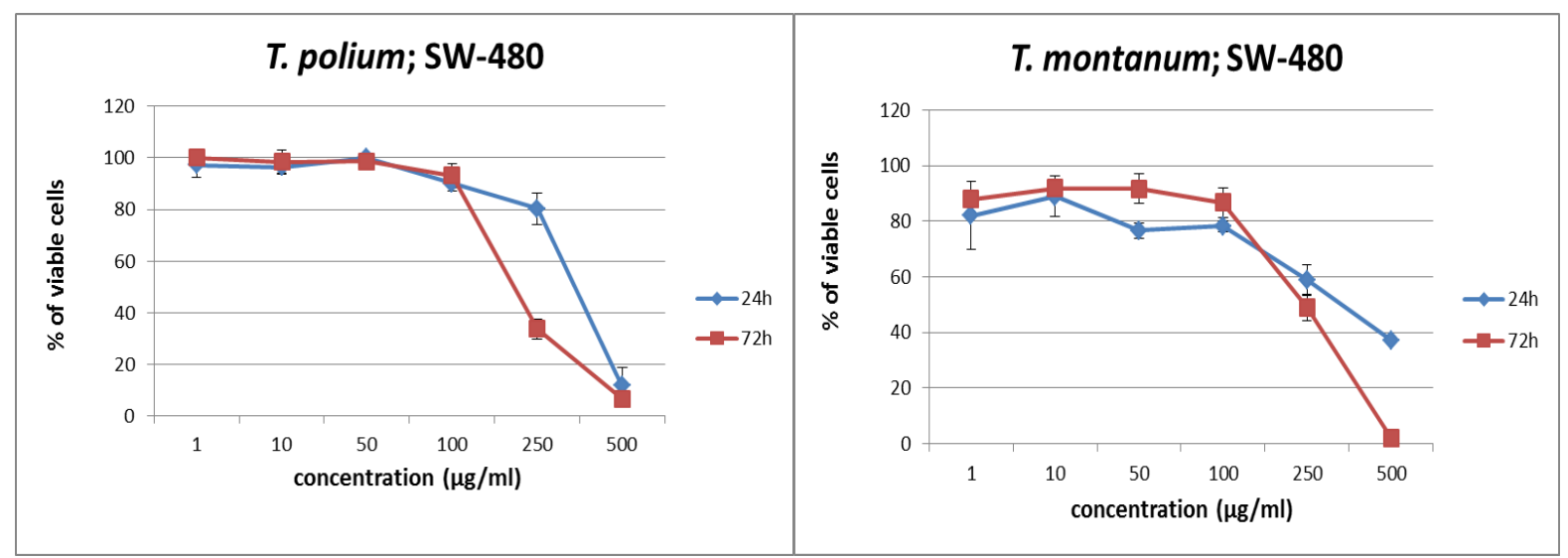

Figure 2. Cytotoxic activity of the methanol extracts from T. polium and T. montanum on SW-480 cell line.

Results are expressed as means \pm SE for three independent determinations. 
Table 1. Cytotoxic activity of $T$. polium and $T$. montanum, expressed as $\mathrm{IC}_{50}$ values $(\mu \mathrm{g} / \mathrm{ml})$ on MDA-MB-231 and SW-480 cell lines.

\begin{tabular}{llll}
\hline Cell line & Treatments & $\mathbf{2 4} \mathbf{~ h}$ & $\mathbf{7 2} \mathbf{~ h}$ \\
\hline MDA-MB-231 & T. polium & $429.37 \pm 0.51$ & $118.26 \pm 1.31$ \\
& T. montanum & $199.32 \pm 0.83$ & $174.39 \pm 1.12$ \\
\hline SW-480 & T. polium & $242.93 \pm 1.24$ & $292.13 \pm 0.59$ \\
& T. montanum & $135.79 \pm 1.04$ & $372.69 \pm 2.34$ \\
\hline
\end{tabular}

Results are expressed as means \pm SE for three independent determinations.

\section{Proapoptotic effects}

The treatments by $T$. polium and T. montanum caused some morphological changes of investigated cell lines, characteristic for apoptosis, like a condensation and chromatin fragmentation, reduction of cell size, membrane blabbing, formation of apoptotic bodies (Figure 3). There are some necrotic cells in the treatments, which are observed as red colored formations. Tables 2 and 3 present the percentage of viable cells, cells in early and late apoptosis and necrotic MDA-MB-231 and SW-480 cells in the investigated treatments, after 24 and $72 \mathrm{~h}$. The investigated treatments mainly caused apoptosis, while necrosis occurred less. We showed dose-dependent MDA-MB-231 cell death, predominantly by early apoptosis after $24 \mathrm{~h}$, as well as late apoptosis and necrosis appearance after $72 \mathrm{~h}$ (especially in treatment by $T$. montanum). There are similar effects on SW-480 cells, with larger number of late apoptotic and necrotic cells. The effects were more pronounced after $72 \mathrm{~h}$ and in the treatment by T. montanum.

A
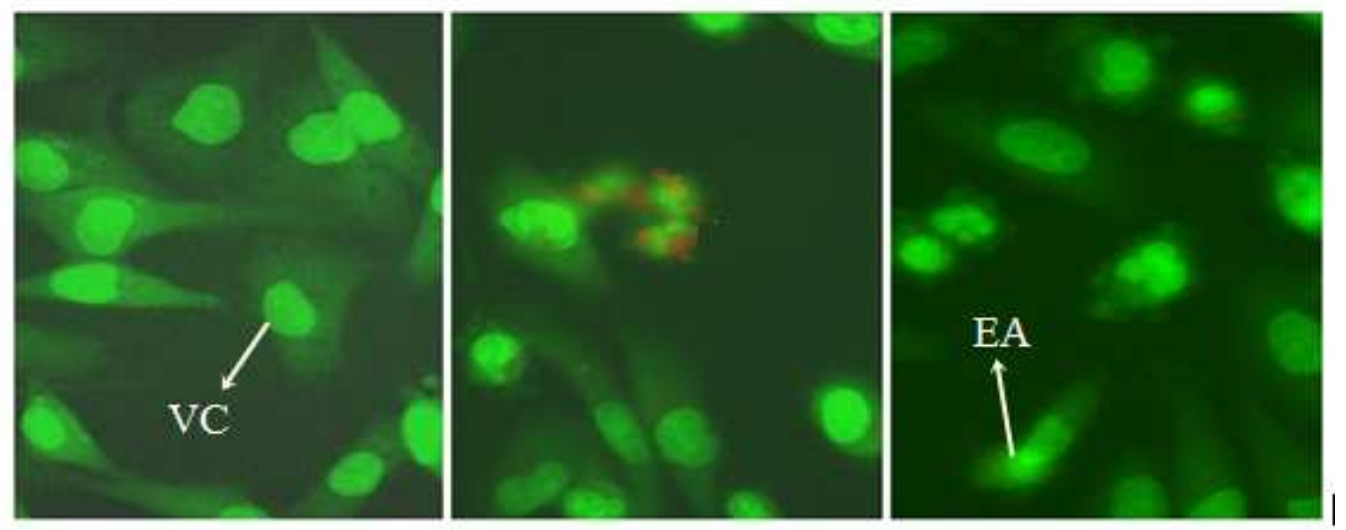

B
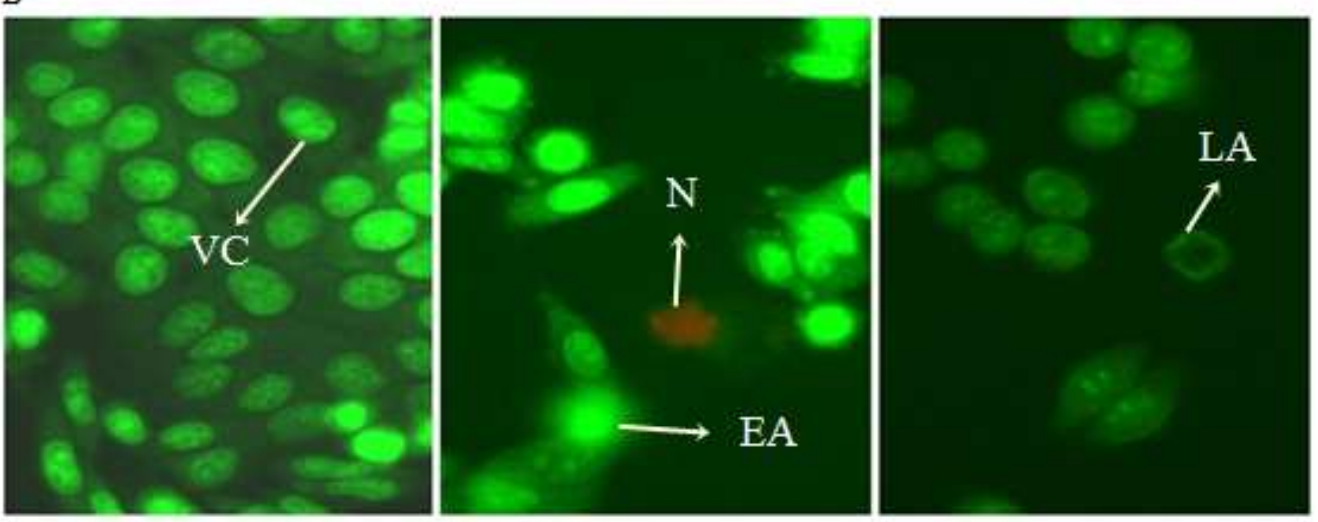

Figure 3. Typical morphological changes (VC-viable cell; EA-early apoptosis; LA-late apoptosis; Nnecrosis) of MDA-MB-231 (A) and SW-480 (B) cells induced by T. polium and T. montanum extracts, stained with AO/EB. The images were taken using fluorescence microscopy at 400x. 
Table 2. Different values of viable, apoptotic and necrotic MDA-MB-231 cells as percentage of total cell number measured by AO/EB fluorescence staining, after treatment by $T$. polium and T. montanum extracts. The percentages of cells were measured 24 and $72 \mathrm{~h}$ after treatments.

\begin{tabular}{|c|c|c|c|c|c|}
\hline & $\begin{array}{c}\text { Concentracion } \\
(\mu \mathrm{g} / \mathrm{ml})\end{array}$ & VC & EA & LA & $\mathbf{N}$ \\
\hline \multicolumn{6}{|c|}{$24 \mathrm{~h}$} \\
\hline Control & 0 & $97.05 \pm 0.25$ & $2.95 \pm 0.25$ & 1 & 1 \\
\hline \multirow{2}{*}{ T. polium } & 50 & $93.4 \pm 0.40$ & $6.45 \pm 0.25$ & / & / \\
\hline & 250 & $89.4 \pm 0.80$ & $10.6 \pm 0.8^{*}$ & I & I \\
\hline$T$. & 50 & $89.95 \pm 0.45$ & $8.2 \pm 1.10^{*}$ & l & $0.85 \pm 0.35 *$ \\
\hline montanum & 250 & $87.65 \pm 1.45$ & $11.35 \pm 0.75 *$ & I & $1 \pm 0.70 *$ \\
\hline \multicolumn{6}{|c|}{$72 \mathrm{~h}$} \\
\hline Control & 0 & $97.3 \pm 0.50$ & $2.7 \pm 0.50$ & I & 1 \\
\hline \multirow{2}{*}{ T. polium } & 50 & $93.9 \pm 0.80$ & $6.1 \pm 0.80^{*}$ & I & I \\
\hline & 250 & $88.00 \pm 0.50 *$ & $11.25 \pm 0.55^{*}$ & $0.35 \pm 0.15$ & $0.4 \pm 0.10 *$ \\
\hline$T$. & 50 & $93.75 \pm 0.05$ & $6.25 \pm 0.05 *$ & / & / \\
\hline montanum & 250 & $87.15 \pm 1.15^{*}$ & $7.7 \pm 0.4^{*}$ & $4.55 \pm 0.55^{*}$ & $0.6 \pm 0.2 *$ \\
\hline
\end{tabular}

Results are expressed as means \pm SE for three independent determinations.

$* \mathrm{P}<.05$ compared to untreated controls.

Table 3. Different values of viable, apoptotic and necrotic SW-480 cells as percentage of total cell number measured by AO/EB fluorescence staining, after treatment by T. polium and T. montanum extracts. The percentages of cells were measured 24 and $72 \mathrm{~h}$ after treatments.

\begin{tabular}{|c|c|c|c|c|c|}
\hline & $\begin{array}{c}\text { Concentration } \\
(\mu \mathrm{g} / \mathrm{ml})\end{array}$ & VC & EA & LA & $\mathbf{N}$ \\
\hline \multicolumn{6}{|c|}{$24 \mathrm{~h}$} \\
\hline Control & 0 & $97.90 \pm 0.1$ & $2.15 \pm 0.15$ & I & 1 \\
\hline \multirow{2}{*}{ T. polium } & 50 & $94.05 \pm 0.35$ & $5.95 \pm 0.35$ & / & I \\
\hline & 250 & $91.35 \pm 0.05$ & $7.85 \pm 0.45^{*}$ & $0.65 \pm 0.55^{*}$ & 0.1 \\
\hline \multirow{2}{*}{ T. montanum } & 50 & $92.05 \pm 0.65$ & $4.85 \pm 0.85$ & $2.8 \pm 0.1^{*}$ & $0.3 \pm 0.1 *$ \\
\hline & 250 & $92.20 \pm 0.3$ & $7.6 \pm 0.2 *$ & $0.2 \pm 0.1^{*}$ & I \\
\hline \multicolumn{6}{|c|}{$72 \mathrm{~h}$} \\
\hline Control & 0 & $95.95 \pm 0.45$ & $4.05 \pm 0.45^{*}$ & I & I \\
\hline \multirow{2}{*}{ T. polium } & 50 & $92.50 \pm 0.9$ & $7.30 \pm 0.9 *$ & 0.2 & I \\
\hline & 250 & $89.9 \pm 0.4$ & $9.45 \pm 0.85 *$ & $0.65 \pm 0.45^{*}$ & I \\
\hline \multirow{2}{*}{ T. montanum } & 50 & $87.75 \pm 0.45$ & $11.4 \pm 0.4^{*}$ & $0.5 \pm 0.2$ & $0.35 \pm 0.15$ \\
\hline & 250 & $89.35 \pm 0.25$ & $9.4 \pm 0.5^{*}$ & $1.05 \pm 0.25^{*}$ & $0.2 *$ \\
\hline
\end{tabular}

Results are expressed as means \pm SE for three independent determinations.

$* \mathrm{P}<.05$ compared to untreated controls.

Protein expression of Fas receptors, as indicator of external proapoptotic pathway, on MDA-MB-231 and SW-480 control and treated cells are presented on Figure 4. Treatments by plant extracts, especially $T$. montanum, significantly increased Fas receptor expression on MDA-MB-231 in comparison with control cells (Figure 4A). Fas receptor expression was more evident on SW-480 control cells than on MDA-MB-231. Treatments by plant extracts showed not so pronounced effects on SW-480 treated cells in comparison with control (Figure 4B). 


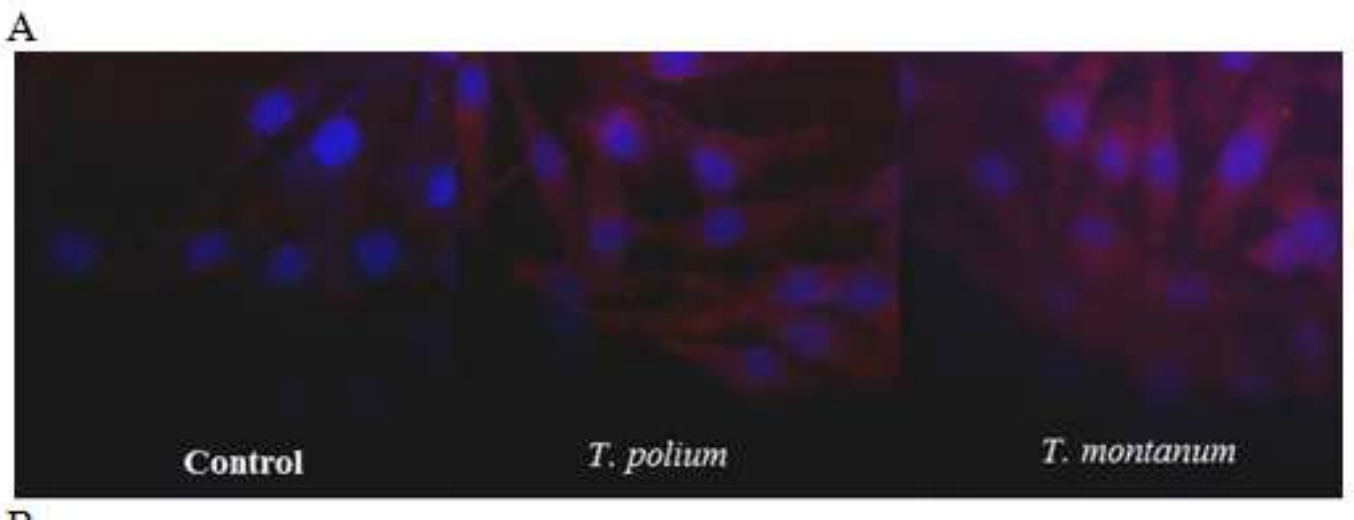

B

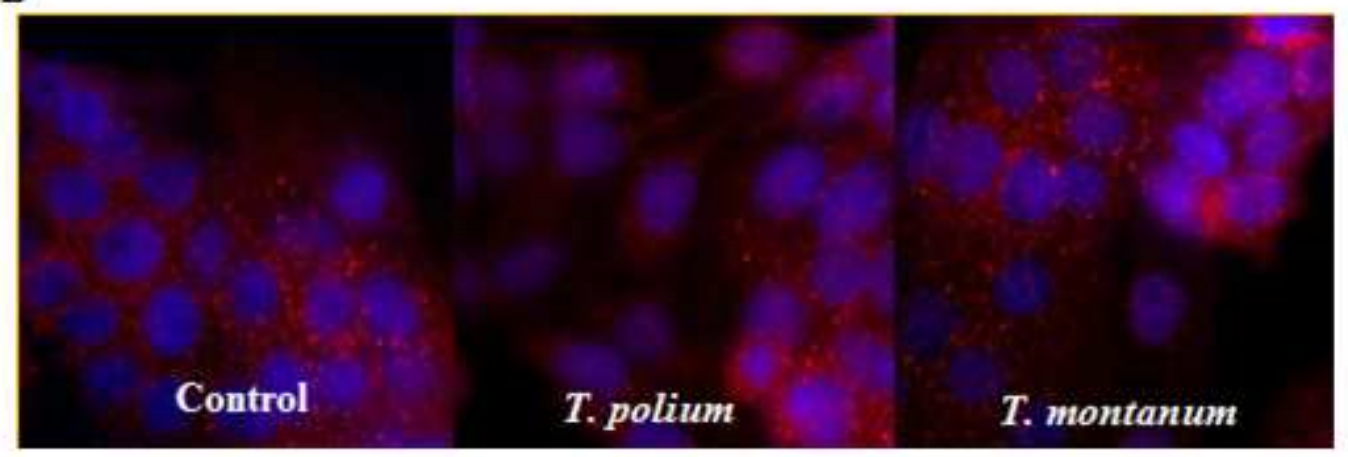

Figure 4. Fas receptors expression on MDA-MB-231 (A) and SW-480 (B) control cells and cells treated by $T$. polium and T. montanum extracts. Cells were incubated with treatments for $24 \mathrm{~h}$.

The images were taken using fluorescence microscopy at $600 \times$.

Nuclei were stained blue, Fas receptors were stained red.

Treatments by plant extracts caused increased caspase 8 activity, an initiator caspase of external apoptotic pathway, in MDA-MB-231 cells, compared to control cells (Figure 5A). This finding is in accordance with the indicated cytotoxic and proapoptotic activity, especially in treatment by $T$. montanum. Investigated treatment caused statistically significant decreasing of caspase 8 activity in SW-480 cells, compared to control cells (Figure 5B). This findings is in accordance with Fas receptor expression and lead to conclusion that apoptosis was not induced by external apoptotic pathway in these cells.

\section{A}

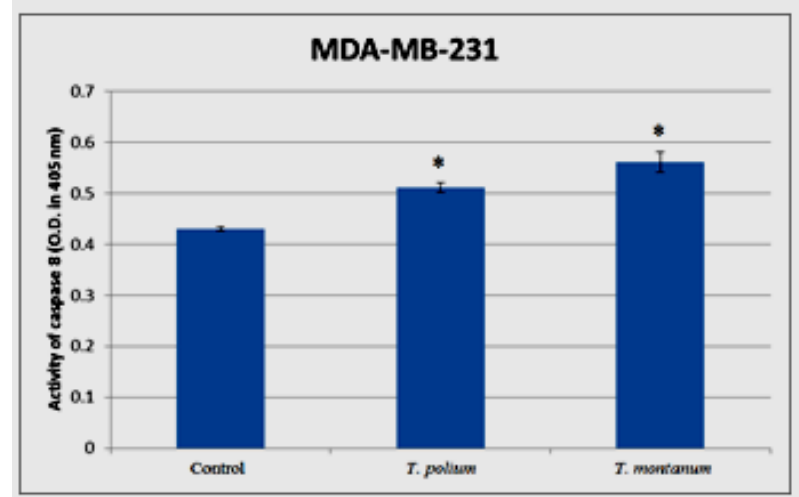

B

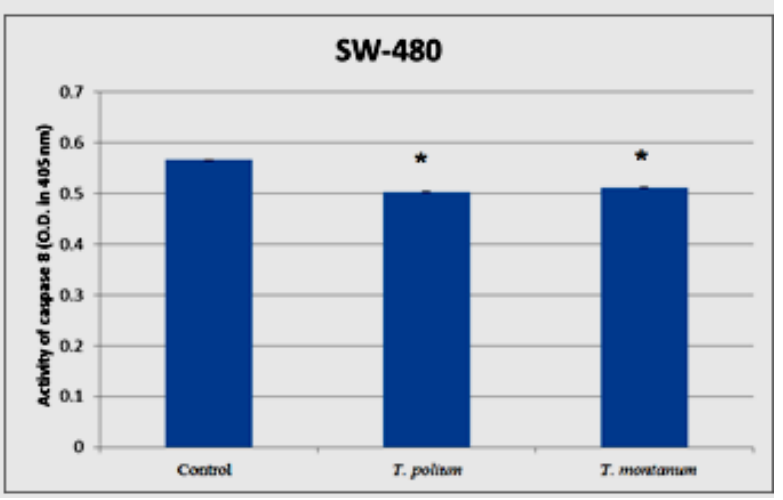

Figure 5. Caspase 8 activity in MDA-MB-231 (A) and SW-480 (B) control cells and cells treated by $T$. polium and T. montanum extracts. Cells were incubated with treatments for $24 \mathrm{~h}$.

Results are expressed as means $\pm \mathrm{SE}$ for three independent determinations.

$* \mathrm{P}<.05$ compared to untreated controls. 
Caspase 9 is one of initiator caspase in internal apoptotic pathway. Activity of caspase 9 was increased in MDA-MB-231 cells after treatments by plant extracts (Figure 6A). Contrary, activity of caspase 9 was decreased in SW-480 cells after treatments by plant extracts (Figure 6B). These findings suggest that process of apoptosis in SW-480 cells is not induced by activity and involvement of these enzymes.

A

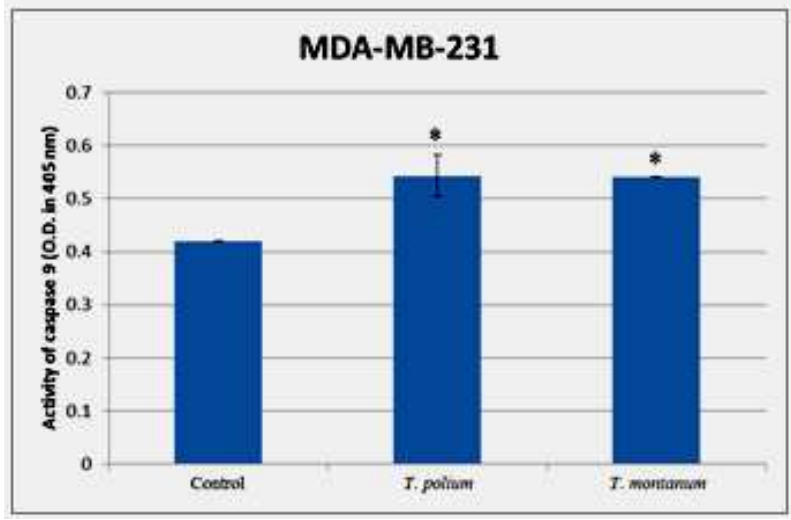

B

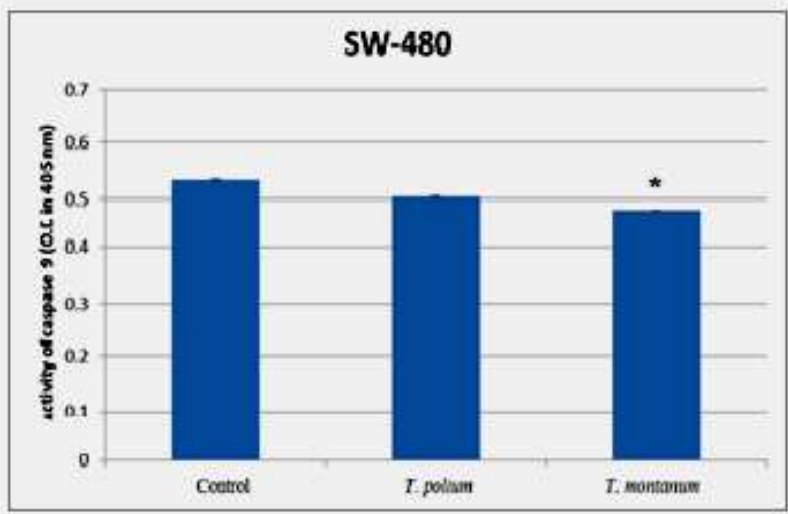

Figure 6. Caspase 9 activity in MDA-MB-231 (A) and SW-480 (B) control cells and cells treated by $T$. polium and T. montanum extracts. Cells were incubated with treatments for $24 \mathrm{~h}$. Results are expressed as means $\pm \mathrm{SE}$ for three independent determinations. $* \mathrm{P}<.05$ compared to untreated controls.

\section{DISCUSSION}

Plants of the genus Teucrium contain phenol compounds with strong biological activity. As medicinal plants they are used in the treatment of conjunctivitis, abscesses, gout, respiratory diseases, gastrointestinal diseases and many others (STANKOVIĆ et al. 2011). In this study cytotoxic and proapoptotic activity of two species from genus Teucrium (T. polium and T. montanum) and mechanisms of induced cell death were investigated. Our results showed that investigated plants showed good cytotoxic and proapoptotic activity on MDAMB-231 and SW-480 cell lines. These plant extracts showed different effects on breast and colon cancer cells. According to our results SW-480 cells are more resistant than MDA-MB231 cells. Similar studies have shown different results regarding the SW-480 cell line, such as research on species of the same genus, $T$. chamaedrys, showing a significant cytotoxic effect on this cell line (STANKOVIĆ et al. 2011).

Specific components in the composition of plant extracts can contribute to a variety of effects on cells, and run specified mechanisms of cytotoxicity (STANKOVIĆ et al. 2010; 2011). In accordance to that, the difference in the effects between the different species of the same genus Teucrium, in this case can be caused by many ecological factors, or depend on the chemical composition of the extracts, which are primarily related to the presence of acids, phenols and flavonoids. High levels of specific flavonoids, as well as their relationship, may alter the cytotoxicity of plants. The difference in the phenolic composition of these plants could be the reason for their different effects, although belong to the same genus (STANKOVIĆ et al. 2011). The most common flavonoid in T. polium is quercetin. Beside the antioxidative, quercetin also exhibits prooxidant effect and can induce apoptosis in response to the increased concentration of superoxide in tumor cells (STANKOVIĆ et al. 2011; RAINA et al. 2013; ŽIŽIĆ et al. 2013). T. montanum mostly contains rutin phenol which greatly contributes to the 
biological effect. The study on plant Allium flavum, which exhibits significant cytotoxicity, showed high prevalence of rutin (KESSLER et al. 2003; MiLUTINOVIĆ et al. 2015).

Investigated extracts predominantly induced apoptosis as a type of cell death in booth cell lines. Generally, plants and different natural products isolated from plants induced apoptosis of cancer cells in in vitro conditions, which presents preferred type of induced cell death in cancer therapy (ĆURČIĆ et al. 2012a; ĆURČIĆ et al. 2012b). Based on our results, except to better cytotoxicity, T. montanum shows stronger proapoptotic effect. The percentage of viable cells is lower when compared to control and in treatment to $T$. polium extract. For the process of apoptosis and regulation of various signaling pathways redox regulation could take a significant role. Changes in the production of reactive oxygen species (ROS) and reactive nitrogen species (RNS) can modify signaling pathways in the cell (ENGLAND and COTTER, 2005). The results of research of plants $T$. polium and $T$. montanum on the redox status on MDA-MB-231 and SW-480 cells show significant prooxidant effects, or increase the level of superoxide anion radicals (StOJANOvić et al. 2015). The high $\mathrm{O}_{2}^{-}$level (superoxide anion radical) could be a significant cause of the cytotoxic and proapoptotic effect of tested plants.

For determination of apoptotic pathways, which are activated in treatment with $T$. polium and T. montanum, we monitored protein expression of Fas receptor and showed significant increase in MDA-MB-231 cells (Figure 4). To determine the mechanism by which the apoptosis occurred we were examined caspase 8 and 9 as signaling molecules. Activity of caspase 8 (the initiator caspase on external pathway) increased as compared to untreated cells. Caspase 9 is also the initiator caspase on internal pathway which starts from the mitochondria. Activity of caspase 9 could be connected with the activity of caspase 8 , because the activation of external pathway can activate internal pathway (WONG, 2011; OUYANG et al. 2012; WEINBERG, 2014). In our study, we observed significant increase of caspase 9 activity in treatment with $T$. montanum extract, in comparison to $T$. polium (Figure 6), and also more significant effect on all monitored parameters of proapoptotic signaling pathways, which is consistent with a stronger cytotoxic and proapoptotic activity in the MDA-MB-231 cells.

SW-480 cells exhibited different behavior. The treatment even reduces the expression and activity of these signaling molecules of external and internal apoptotic pathways in these cells. Expression of the Fas receptor in the control SW-480 cells suggests that they were also be able to express this receptor and activate apoptosis without any treatment (RYAN et al. 2006). Phenolic compounds, which are present in plants, may affect the activity of many cell receptors and enzymes (MIDDELTON et al. 2000), so the results could be related to the chemical composition of the extract. Some literature data indicate that SW-480 cells belong to type of the cells that may enter into apoptosis and that could be completely independent of the mitochondria, although in many other types of cells this is not the case (OzOREN and ELDEIRY, 2002). Since the SW-480 cells reduced the level of caspase 8 and caspase 9 activity, this indicates a potential caspase-independent apoptosis.

\section{CONCLUSION}

Finally, we concluded that examined species of plants induce apoptosis in different ways, and this behavior is prominent in MDA-MB-231 cell line. When compared two tested plant species, T. montanum shows a better cytotoxic activity than $T$. polium. Investigated plants could be considered as potential source of natural bioactive substances in antitumor therapy. 


\section{Acknowledgments}

The authors are grateful to the Ministry of Education, Science and Technological Development of the Republic of Serbia for financial support (Project No. III41010).

\section{References:}

[1] Alberts, B., Johnson, A., Lewis, J., Raff, M., Roberts, K., Walter, P. (2008): Molecular Biology of the Cell. 5th Ed. Garland Science, New York.

[2] Baskić, D., Popović, S., Ristić, P., Arsenijević, N. (2006): Analysis of cyclohexamide-induced apoptosis in human leukocytes: Fluorescence microscopy using annexin V/propidium iodide versus acridin orange/ethidium bromide. Cell Biology International 30: 924-932.

[3] Boranić, M., ŠAmiJa, M., JuzBašić, S., ŠEPAROvić, V., Velemir, D. (2006): Etiology and pathogenesis of breast cancer. Medicinski vjesnik 1 (4): 33-42.

[4] CRagG, G.M., Newman, DJ. (2005): Plants as sources of anticancer agents. Journal Ethnopharmacology 100: 72-79.

[5] ĆurČić, M., Stanković, M., Mrkalić, E., Matović, Z., Branković, D., CvetKović, D., ĐAČIĆ, D., MARKOviĆ, S. (2012a): Antiproliferative and proapoptotic activities of metanolic extracts from Ligustrum vulgare L. as an individual treatment and in combination with palladium complex. International Journal of Molecular Science $\mathbf{1 3}$ (2): 2521-2534.

[6] ĆurČić, M., Stanković, M., Radojević, I., Stefanović, O., ČOMIĆ, Lu., Topuzović, M., ĐAČı́́, D., MARKoviĆ, S. (2012b): Biological effects, total phenolic content and flavonoid concentracions of fragrant yellow onion (Allium flavum L.). Medicinal Chemistry 8 (1): 46-51.

[7] England, K., CotTer, T.G. (2005): Direct oxidative modification of signaling proteins in mammalian cells and their effects on apoptosis. Redox Report 10: 237-245.

[8] Gree, J., Hurrell, R., Leth, T., SAndBerg, A.S. (2001): Food for Health - an Insight into Natural Bioactive Compouds of Plants. In: Frolich, W., DOKKuM, W.V., Chesson, A. (eds.) Cost 916 Action, Office for Official Publications of the European Communities.

[9] Hasani-Ranjbar, S., Nayebi, N., Larijani, B., Abdollahi, M. (2010): A systematic review of the efficacy and safety of Teucrium species; from anti-oxidant to anti-diabetic effect. International Journal of Pharmacology 6: 315-325.

[10] Higuchi, H., Bronk, SF., Takikawa, Y., Werneburg, N., TAKimoto, R., El-Deiry, W., Gores, G.J. (2001): The bile acid glycochenodeoxycholate induces TRAILReceptor 2/DR5 expression and apoptosis. Journal of Biological Chemistry 276: 3861038618.

[11] Kessler, M., Ubeaud, G., Jung, L. (2003): Anti and pro-oxidant activity of rutin and quercetin derivates. Journal of Pharmacy Pharmacology 55 (1): 131-142.

[12] Rosenberg, S.M., Ruddy, K.J., TAmimi, R.M., Gelber, S., Schapira, L., Come, S., Borges, V.F., LARsen, B., Garber, J.E., PATRIDGe, A.H. (2016): BRCA1 and BRCA2 
mutation testing in young women with breast cancer. JAMA Oncology, DOI:10.1001/jamaoncol.2015.5941

[13] Middeleton, E., Kandawami, C., Theoharides, T.C. (2000): The effects of plant flavonoids on mammalian cells: implantation, heart disease, and cancer. Pharmacology Reviews 52: 673-751.

[14] Milić, A., Damnjanović, I. (2013): Use of nonsteroidal antiinflamatory drugs for chemoprevention of colon cancer. Rational Therapy V (1): 17-20.

[15] Milutinović, M., Stanković, M., Cvetković, D., Maksimović, V., Šmit, B., PAVlOVIĆ, R., MARKOVIĆ, S. (2015): The molecular mechanisms of apoptosis induced by Allium flavum L. and synergistic effects with new-synthesized Pd(II) complex on colon cancer cells. Journal of Food Biochemistry 39 (3): 238-250.

[16] Mosmann, T. (1983): Rapid colorimetric assay for cellular growth and survival: application to proliferation and citotoxicity assays. Journal of Immunology Methods $\mathbf{6 5}$ : 55-63.

[17] Newman, D.J., CragG, G.M., SnAder, K.M. (2003): Natural products as sources of new drugs over the period 1981-2002. Journal of Natural Products 66: 1022-1037.

[18] NiJveldT, R.J., VAN NoOd, E., VAn HoOR, D.E., BoElens, P.G., VAN NORRENK K, VAN LEEUWEN, P.A. (2001): Flavonoids: a review of probable mechanism of action and potential application. American Journal of Clinical Nutrition 74 (4): 418-425.

[19] OuYang, L., Shi, Z., Zhao, S., Wang, F.T., Zhou, T.T., Liu, B., BaO, J.K. (2012): Programmed cell death pathways in cancer: a review of apoptosis, autophagy and programmed necrosis. Cell Proliferation 45: 487-498.

[20] Ozoren, N., EL-DeIRY, W.S. (2002): Defining characteristics of types I and II apoptotic cells. Neoplasia 4 (6): 551-557.

[21] Raina, K., Tyagi, A., Kumar, D., Agarwal, C. (2013): Role of oxidative stress in citotoxicity of grape seed extracts in human breast cancer cells. Food and Chemical Toxicology 61: 187-195.

[22] Ravelo, A.G., Estévez-Braun, A., Chávez-Orellana, H., Pérez-Sacau, E., MesaSIVERIO, D. (2004): Recent studies on natural products as anticancer agents. Current Topics Medicinal Chemistry 4 (2): 241-265.

[23] Ryan, A.E., Lane, S., Shanahan, F., O’Connell, J., Hpuston, A.M. (2006): Fas ligand expression in human and mouse cancer cell lines; a caveat on over-reliance on mRNA data. Journal of Carcinogenesis 5: 5.

[24] Stanković, M., Topuzović, M., Marković, A., Pavlović, D., Solujić, S., NiĆIfOROVIĆ, N., MiHAILOVIĆ, V. (2010): Antioxidant activity, phenol and flavonoid contents of different Teucrium chamaedrys L. Extracts. Biotechnology \& Biotecnological Equipment 24 (2): 82-86.

[25] Stanković, M., Ćurčić, M., Žižić, J., Topuzović, M., Solujić, S., Marković. S. (2011): Teucrium plant species as natural sources of novel anticancer compouds: antiproliferative, proapoptotic and antioxidant properties. International Journal of Molecular Science 12 (7): 4190-4205.

[26] Stanković, M., Mitrović, T., Matić, I., Topuzović, M., Stamenković, S. (2015): New Values of Teucrium species: in Vitro Study of Cytotoxic Activities of Secondary Metabolites. Notulae Botanicae Horti Agrobotanici 43 (1): 41-46. 
[27] Stojanović, A., ŽIVAnović, M., Marković, S. (2015): Effects of extracts of Teucrium spp. On viability, migration potential and redox status of colon cancer (SW-480) and breast cancer (MDA-MB-231) cell lines. Third Congress of the Serbian Society for Mitochondrial and Free Radical Physiology "Redox Medicine. Reactive Species Signaling, Analytical Methods, Phytopharmacy, Molecular Mechanisms of Disease". Belgrade, P7, pp. 28 [Abstract in English]

[28] Suffness, M., Pezzuto, J.M. (1990): Assays related to cancer drug discovery. In: Hostettman, K. (Ed.) Methods in Plant Biochemistry: Assay for Bioactivity. Academic Press, London, pp. 71-133.

[29] WeInBerg, R.A. (2014): The Biology of Cancer. 2nd ed., Garland Science, New York and London.

[30] Wong, R.S. (2011): Apoptosis in cancer: from pathogenesis to treatment. Journal of Experimental Clinical Cancer Research 30: 87.

[31] Yin, G., ZENG, H., HE, M., WANG, M. (2009): Extraction of Teucrium manghuaense and evaluation of the bioactivity of its extract. International Journal of Molecular Science 10: 4330-4341.

[32] Žižıć, J.B., Vuković, N.L., Jadranin, M.B., AnĐelković, B.D., TeŠEvić, V.V., KaCAniova, M.M., Sukdolak, S.B., Marković, S.D. (2013): Chemical composition, cytotoxic and antioxidative sctivities of etanolic extracts of propolis on HCT-116 cell line. Journal of the Science of Food and Agriculture 93 (12): 3001-3009. 